\title{
Collective Belief and the Intentional Strategy ${ }^{1}$
}

\author{
David Kocourek \\ Filozofická fakulta \\ Univerzita Hradec Králové \\ Rokitanského 62, 50003 Hradec Králové \\ david.kocourek@uhk.cz
}

What do we mean when we say that some group believes something? Do we simply mean that all the members of the group believe it, or are we acknowledging the existence of some kind of group agent? According to Margaret Gilbert, talk about group mental states refers to the specific kind of agreements she calls joint commitments - that is, to collectively believe something means to be committed with others to believe it. In my article, I will first present Gilbert's approach in more detail but will ultimately show that this approach is problematic and will refute it. I will briefly consider the most common solution to the problems Gilbert's account faces, which lies in replacing collective beliefs with acceptances, but I will show that this solution will not do either. The solution I will then present will be based on Daniel Dennett's intentional strategy, which is a method of interpreting the things around us and predicting their behaviour by treating them as rational agents with relevant intentions. I will try to show that all the problematic cases of collective belief can be explained by applying the intentional strategy to the groups in question.

Key words: Collective belief, Daniel Dennett, Intentional strategy, Joint Commitment, Margaret Gilbert

What do we mean when we utter sentences such as: "Christians believe in the afterlife", "The government wants to raise the minimum wage" or

1 Work on this paper was supported by the joint Lead-Agency research grant between the Austrian Science Foundation (FWF) and the Czech Science Foundation (GAČR), Inferentialism and Collective Intentionality, GF17-33808L. 
"Students like to party on Friday nights"? On one hand we could surely interpret these sentences as saying that every member of the group in question (or at least an overwhelming majority of its members) has the property in question - that every Christian believes in the afterlife, every member of the government wants to raise the minimum wage, and every student likes to party on Friday nights. This interpretation is often called a simple summative account - but we would probably feel that there might be something wrong with this interpretation, because while it seems quite plausible to claim that every Christian believes in the afterlife, it seems less plausible to say that every student likes to party on Friday nights - and it seems very implausible to think that all members of any government would ever agree on anything. Yet, we do often use sentences like these, and we generally do not consider them to be plainly false. But how then should we interpret them? British philosopher Margaret Gilbert has proposed the so-called plural subject account of collective belief, according to which it is possible for social groups to have beliefs, emotions and mental states in general that are not necessarily shared by all their members. In the following article I will first present in detail Gilbert's approach to collective belief, then I will attempt to point out some of its problematic implications and offer a different solution to the phenomenon in question.

The key concept in Gilbert's plural subject account is joint commitment. What is joint commitment? Gilbert usually explains it by contrasting joint commitment with a simple personal commitment: we create personal commitments every time we make a decision to do something. For example, when I decide to, say, write a grant proposal tonight, this decision will in itself not only give me a reason to perform this action ("I am going to write a grant proposal tonight because I have decided to do so"), but it will also create an obligation to act on that decision ("I must write a grant proposal tonight because I have decided to do so"). Therefore, should I forget about my decision and go to the pub instead, I could, when I have remembered that I have made a personal commitment to write a grant proposal tonight, say something like "Oh no, I should have been writing" - that is, I could recognize my current action as wrong, since this action contradicts my previous personal commitment. Of course, 
the obligations created by personal commitments are always only to myself, and I can easily change them just by changing my mind - but this will not be the case once we get to joint commitments. ${ }^{2}$

Joint commitments arise when two or more people decide to do something together. The most important thing about joint commitments is that they are not the sum of two (or more) separate commitments to do the respective parts of a collective task - rather, a joint commitment is one commitment binding a number of people at once. If, for example, you and I have a joint commitment to go see a movie together, it is not just a combination of my commitment to go see a movie and your commitment to go see a movie. If I manage to deliver on my part and get to the cinema on time, but you do not, I would not say that I have succeeded in our task and you have not - no, if you do not show up, then we both fail. The formula that Gilbert herself uses to define joint commitment is this: persons $a, b$, $c$, etc. are jointly committed to do $x$ as a body ${ }^{3}$ - meaning all the individual members of the group are committed to successfully carrying out action $x$ as if one metaphorical person was doing $x$. Sure, they will most likely divide the work somehow - one person will do this, another that - but they can only all succeed or all fail, there is only one commitment that they all share together.

This might, at least at first sight, seem like an interesting approach to the problem of collective action, but Gilbert also uses joint commitment when she explains collective beliefs and other collective mental states. ${ }^{4}$ The formula here is very similar to the one we saw above: a group (population, collective, etc.) A believes that $p$ if all the members of $A$ are jointly committed to believe that $p$ as a body. ${ }^{5}$ And this is where the problems with Gilbert's account start, because while it makes sense to say that members of a group agree to commit themselves to carry out an action, it is not easy to see how they could commit themselves to feel or believe something. We generally do not think that an individual could do such a thing, so how come group members can? To get a better idea of how Gil-

2 Gilbert (2002a, p. 31), Gilbert (2004, p. 173).

3 Gilbert (2002b, p. 138).

4 For example, Gilbert (2002c) uses the plural subject account to analyse collective guilt feeling.

5 Gilbert (2004, p. 173). 
bert thinks this works, we should look at one specific example she often presents: imagine a poetry club that regularly reads and discusses poetry. At the end of every meeting the members of the club try to formulate their opinions on the poem they were reading that day and attempt to formulate some collective assessment of the poem in question. Now, let us say that after reading a poem one day, one of the members opens the discussion by claiming that she loves the poem. Another member joins her, and the next one says she kind of likes it too. The rest of the members maybe nod in agreement or at least do not explicitly disagree. Now we could - according to Gilbert - say that the poetry club likes the poem in question, that the club believes the poem is good, simply because all members of the club have agreed on this position. But despite this, it is quite possible that none of the members actually liked the poem personally! Maybe the first member who claimed to like it just liked the author and wanted to support her, even though she did not actually like this particular poem. Maybe the second supporter of the poem did not really like it either, she just wanted to impress (for whatever reason unrelated to poetry) the first member by agreeing with her. And maybe the rest of the group just did not feel like arguing, and so they simply agreed with the first opinion suggested. In any case, we now have a collective belief that the poem is good (i.e. a group of people jointly committed to belief as a body that the poem is good) without any such personal belief. ${ }^{6}$

From this it could look like the group members can "decide" to believe something, because it is not they who in the end believe it, it is a group agent, a plural subject, that they created together - and since they have created this subject, they get to decide its beliefs. But this cannot be right - Gilbert does not think that collectives could create some actual new subject, a new "group mind" ontologically different from the individual members. All the talk about emulating a body is more of a metaphor: the individual members merely act as if they composed an agent. ${ }^{7}$ But if this is the case, if the belief "The poem is good" from our example is not a simple belief of some collective subject but a collective belief of individual members of the poetry club, how is it possible that they can

6 See e.g. Gilbert (1987, pp. 190-194), Gilbert (2004, pp. 168-169).

7 Gilbert (2014, p. 9). 
collectively believe that the poem is good and individually believe that it is not good at the same time? Gilbert is willing to accept this problematic conclusion, claiming that this is simply how we use collective beliefs in our everyday talk - and if traditional epistemological understanding of belief is different, then so much the worst for epistemology ${ }^{8}-$ but it probably comes as no surprise that many authors do not agree with this conclusion. ${ }^{9}$

The most common objection against this approach is the claim that the collective belief described by Gilbert is not actually a belief but rather an acceptance. Several differences between belief and acceptance have been suggested..$^{10}$ In my opinion the most important are the following:

(1) Acceptance is voluntary, belief is not. As was already mentioned, groups can, according to Gilbert, decide what they will take for their "belief". This is not the case for individuals. What individuals can do, however, is to decide to accept something. This happens when we say things like: "Let's imagine for now that she did it" or "Ok, I will agree on this but it's just so we can move on"; that is, when we accept a proposition e.g. for the sake of a discussion or to compromise. We do not really believe it, but we merely act as if we believed it for some pragmatic reason. Which gets us to the second point:

(2) Belief necessarily aims at truth, acceptance does not. As we saw in the poetry club example, the group can decide to "believe" something for pragmatic reasons rather than for its truth value. Gilbert presents more examples like this: take a campus improvement committee that "believes" that a new café could improve the campus. But the reason for this "belief" is that the Chancellor wants the new café on campus and

8 Gilbert (2004, p. 178).

9 For various critiques of Gilbert's account see e.g. Hakli (2007), Mathiesen (2006), Sheehy (2006, primarily chapter two), Tuomela (2000). See also Tollefsen (2015, primarily chapter one) for a brief comparison of Gilberts account with some other possible approaches.

10 But see Schmitt (2014) for some interesting objections against these differences. 
nobody in the committee dares to disagree with the Chancellor. ${ }^{11}$ Again, in the individual case we would not call this a belief - on the contrary, we can quite easily imagine some individual member of this committee saying something like "I don't think this campus needs a new café, but I can't say that in front of the Chancellor". One can only believe something if she considers it true (and vice versa, one can only consider something true if she believes it). ${ }^{12}$ But this is not the case for acceptance.

(3) Belief may come in degrees, but acceptance does not. When talking about belief, we often claim that we consider something possible, probable, almost certain, etc. That is, we can believe or doubt something just to a certain degree. This is usually not the case with acceptance - if we understand acceptance as voluntary action taken for pragmatic reasons, there is no need for doubts. We can accept (or refuse) a "belief" - full stop. In the cases of group beliefs described by Gilbert, it looks like the groups always decide to believe absolutely - the poem is good; the café is needed - there are no "buts" or "maybes" in these cases.

What would it mean to replace belief with acceptance? Gilbert would say not that much - we can have semantic discussions about whether to call the phenomenon in question belief or acceptance all we want, but the important thing - the fact that there are some collective mental states - still remains true. ${ }^{13}$ This would indeed be correct for accounts that refuse group beliefs but allow group acceptances, ${ }^{14}$ but I think that once we substitute acceptance (in the sense described here) for belief, we can also get rid of the "collective" part of the equation. To explain

11 Gilbert (2002b, p. 152).

12 One could point to cases where we say things like: "I can't believe it's raining on my wedding day" or "I know my sister is dead, I just can't believe it." I consider these cases metaphorical, describing a huge disappointment or sadness about the state of affairs in question. If pressed, I am sure that the speaker of such sentences would admit that she actually does believe that it is raining or that her sister is dead.

13 Gilbert (2002b, p. 160).

14 This is the case in e.g. Tuomela (2000). 
this, we need to return to the beginning of this article for a moment. There I said that some apparent group beliefs can be explained as only referring to individual beliefs of all (or the vast majority of) the members - the example was that the sentence "Christians believe in the afterlife" might literally mean that every single Christian indeed does believe in the afterlife. We have called this approach a simple summative account. We have also said that this approach cannot explain all the cases of collective belief - in Gilbert's example of the poetry club, the statement "The club believes that the poem is good" cannot possibly be explained by the simple summative account since, as we saw, no member of the club actually believed that the poem was good individually. But does the same hold for acceptance? It seems to me that it does not, because we can say about every member of the club individually that she accepted (that is - according to our specification of acceptance - voluntarily decided for pragmatic reasons to treat as definitely true) the proposition "The poem is good". So, let us now consider whether any case of so-called group "belief" might actually be just a case of individual acceptance.

In both of Gilbert's examples presented here, the view that collective belief is just individual acceptance holds. The case of the campus improvement committee is very similar to the case of the poetry club (we can similarly say that all the members of the committee have individually, voluntarily accepted, out of fear of the chancellor, that the campus without a doubt needs a new café). Even the examples we started this text with might fit this interpretation. Here, the claim about Christians and the claim about students are interpretable simply by the simple summative account (they might still, of course, be false; it might turn out for example that many students actually do not like to party on Friday nights), and the sentence "The government wants to raise the minimum wage" could be interpreted the same way as the cases of the poetry club or the campus improvement committee. Most of the members might not actually believe that the minimum wage should be raised, but they have accepted this position as a part of some negotiation. But there are other examples that are more complicated than this. We will now consider some of these: 
First example: take elections or any other kind of large-scale voting. When the voting is done, commentators might say things like "The citizens of this particular country believe that the elected party can solve the ongoing crisis" or - to give a more specific example - "The Britons wanted to leave the European Union". Most of the time in such elections it is not the case that a big enough majority voted for the winning party (or for leaving the EU) to explain such cases with the simple summative account - but neither does there seem to be any kind of joint commitment to accept (and definitely not to believe) the outcome of the election - as is shown by occasional after-election demonstrations and frustrations of the losing sides.

Second example: suppose that a government is deciding whether to invest more money into the army. The decision to do this might be based on the government's belief on whether or not the country is under threat of an imminent attack. Imagine now that the government is divided: some of its members strongly believe that there is no threat of such an attack, others are absolutely certain that the attack is bound to happen. It is possible then that the government decides to invest some sum of money into its military because it has a reason to "believe that the attack is somewhat probable". In this example, not only do none of the individual members believe or accept that the attack is "somewhat probable" (they collectively agreed on an amount of money they will spend on the army but all still hold to their previous beliefs that the attack is either very or not at all probable), but also this collective belief of the government comes in degrees - somewhat probable - and therefore cannot be a case of acceptance as defined here. ${ }^{15}$ 
Third example: imagine that the chief of the police force gets (from an outside source) some important information about a crime going on. Further, imagine that the perpetrators of this crime at the same time get the information that the chief of the police has been informed about their activity. They can now say something like "Oh no, the police know about us". This claim, it seems to me, would be quite justified since it is reasonable to expect that the police will take some action. And yet the vast majority of the police officers do not know, nor believe, nor accept that the criminal activity is happening - the chief is the only one who got the information. ${ }^{16}$

Not only can these three cases not be explained as referring to the individual acceptances of all the group members, they also cannot be explained by Gilbert's original plural subject account of collective belief - not even if we substitute collective belief with collective acceptance! And Gilbert cannot just get rid of them by saying that they are merely illusory cases of collective belief, because her own argument for treating collective beliefs as genuine beliefs and not just metaphors relies on the claim that we should respect what we call belief in natural language. So, to justify Gilbert's approach to collective belief, we would either have to show how to explain the examples above using the plural subject account or suggest a way to distinguish metaphorical collective beliefs from real ones (and such a way would have to eliminate our problematic examples while still allowing Gilbert's examples and would have to do this without referencing the plural subject account itself to avoid circularity). But I do not think we should go through all this trouble. In the rest of this paper, I will rather try to propose an analysis of the phenomenon that could explain all the examples we have presented so far without needing to invoke any form of plural subjects or collective mental states.

In short, the solution I want to propose is to treat any group that could be said to have mental states independent of the mental states of its members (that is, the cases that could not be easily interpreted by the simple summative account - though I will later argue that we certainly

16 Cf. Hakli (2007, p. 255). 
should use the simple summative account more often than Gilbert seems to suggest) as an intentional system - as an agent whose behaviour can be predicted or interpreted by the so-called intentional strategy proposed by Daniel Dennett. ${ }^{17}$ The view I want to defend is that groups, of course, cannot have mental states in the same sense that we generally think humans do - but it is sometimes nevertheless reasonable to treat them as if they did. In what follows, I will first explain in more detail what Dennett means by using the intentional strategy (or, in other words, assuming an intentional stance), and then I will try to show how this approach solves the problematic examples presented so far..$^{18}$

We are, according to Dennett, "assuming a stance" when we aim to understand the world around us, to interpret it, to predict its future states and actions. But the aforementioned intentional stance is not the only stance that we can assume - there is also what Dennett calls the physical stance and the design stance. You assume a physical stance when you are trying to predict the behaviour of an object based on the physical constitution of the object in question and the natural laws it obeys. You can assume this stance to easily predict, for example, what a rock thrown out of the window will do: it will fall down (and possibly break something at the end of its fall) due to its weight and the law of gravity. The physical stance can be applied quite universally, but only as long as you know the physical laws binding the future actions you are trying to predict. You can often find yourself in a situation when you want to know how something will act without knowing enough about its inner composition or about the physical laws that govern its behaviour. In such cases you will resort to one of the other two stances. You assume a design stance when you attempt to predict the behaviour of an object based on your knowledge of the design or function of that object. For example, if you guess what will happen when you turn the ignition key in your car, you would probably not think about how the battery, the ignition system or the engine work. You simply do not know enough about the car's engineering to predict its behaviour from its physical proper-

17 E.g. Dennett (1971), Dennett (1981).

18 Dennett did not use the intentional strategy to interpret group behaviour himself - as far as I know, the first one to apply the intentional strategy to groups was Tollefsen (2002), who uses it to interpret intentionality of organizations. 
ties (unless you are a professional car mechanic or a car enthusiast, who might do just that in his everyday work). What you most likely do know, however, is how cars are generally designed to work. You know that unless something is broken, a car's engine will start when the ignition key is turned - and therefore, assuming a design stance, you would make exactly that prediction. Last but not least, there is the intentional stance. You assume this stance every time you try to understand the behaviour of something based on its intentions - its beliefs, wishes, desires and other mental states you presume it to have. You of course assume this stance towards other human beings: You can predict that your friend will take an umbrella when she leaves her home not because you try to understand the natural laws binding her every move, nor because you consider her somehow designed to carry an umbrella with her when she goes out, but because you assume that she has a belief that it is raining outside and also a desire not to get wet. But you can, according to Denne$\mathrm{tt}$, resort to the intentional strategy in other situations as well. We often use it when we talk about animals (even though to some people ascribing verbalized beliefs or other mental states to animals might be philosophically uncomfortable ${ }^{19}$ ). We can even assume an intentional stance towards machines or programs - for example, the best strategy to predict the moves of a chess-playing program is to treat it as an agent that wants to win a game (and also believes that you want to win the game, knows how the chess pieces move, intends to play a certain strategy, etc.). To say that something has mental states means nothing more than saying that you assume an intentional stance towards it, that it is interpretable by an intentional strategy. In this sense, according to Dennett, even animals or objects can have mental states.

It would seem that the physical stance is the most fundamental, the most precise description of reality. Is it not, after all, a goal of many branches of cognitive science to find out how human brains really work - to be able to describe thoughts, wishes or intentions just as synaptic transmissions between neurons? Well, that depends on what we are interested in. If we are trying to discover natural laws that human brains

19 See Rowlands (2012, primarily chapter two) for an interesting approach to the problem of ascribing intentional states and propositional content to animals. 
abide by, then, sure, we must treat brains as systems interpretable by assuming a physical stance. But if we are interested in how human society works, what human reasoning and decision making actually look like in society, then ignoring the intentional strategy would mean missing a crucial part of the process. I want to argue now that we can assume these three stances not only towards objects, animals or individuals, but also towards groups, and that - as well as in the case of describing human thoughts - while every group is in the end reducible to a more basic level (in this case to the thoughts of its individual members, which could then, of course, be reduced even further to the processes in their brains), we really do use the intentional strategy when talking about groups on a daily basis - and therefore ignoring it would mean ignoring an important part of how human society works.

On this account, assuming a physical stance towards a group would be, as I have already indicated, analogical to the simple summative account approach - we would be predicting the behaviour of a group just by predicting the actions or mental states of all the individual members. When we know all relevant information about all relevant individuals, we can surely predict or explain their behaviour without endorsing the group at all. But just as we often do not know all the laws and mechanisms necessary to assume the physical stance towards objects around us, we often do not have enough information about all the individuals we are interested in. And this is when we resort to intentional strategy - this is why we talk about groups as if they had thoughts and beliefs and desires. Obviously, the government does not want to raise the minimum wage in the same sense that I want to do something (unlike me, government does not have mind), but if we do not know the motivations and intentions of all individual members of the government, treating the whole group as one agent with its own motivations and intentions - that is, assuming an intentional stance towards it - might just be the next best strategy to understand what is going on. And finally, even though we have not really talked about this aspect of group behaviour so far, we could surely also assume a design stance towards some specific kinds of groups: for example, we could predict that if the police encounter criminal activity, they will try to 
stop it rather than join in, since it is a purpose of the police to stop crime - police forces are designed to do just that. ${ }^{20}$

Armed with the intentional strategy, we can now try to resolve all the problematic cases that led Gilbert and others to believe that postulating collective mental states is necessary. Let us start with simple situations of small collectives that do not form any kind of social group or institution. Gilbert, for example, presents a case of two friends, Roz and Mark, who believe that defensive war is justified. ${ }^{21}$ If Roz says: "We think that defensive war is justified", it can mean (in Gilbert's analysis) one of two things: first, it might be a simple summative account statement claiming that Roz believes that defensive war is justified and Mark just happens to have the same opinion. Second, it could be a case of collective belief - that is, it might mean that Roz and Mark have formed a joint commitment to believe as a body that defensive war is justified. Gilbert's main argument for the second possible interpretation is that, should Mark now all of a sudden say that he does not believe that defensive war is justified (maybe he just said that before because he wanted Roz to like him), Roz will feel that Mark has offended her somehow (and he will understand that she has the right to feel that way). According to Gilbert, the reason for this feeling has its roots exactly in the violation of their joint commitment, in betraying their collective belief. I disagree - it se-

20 It needs to be said here that my interpretation of Dennett's intentional strategy is very instrumentalist, that is, I am treating the intentional stance mainly as a tool, a useful metaphor. But that is quite different from how Dennett himself intended to understand the strategy. His own approach is in fact interpretationist. According to him, there is really nothing more to intentionality than being interpretable by the intentional strategy - and therefore there is no real difference between the intentionality of individual humans and intentionality of machines or groups. Tollefsen (following Dennett) characterizes this position as "mild" or "intermediate" realism: group beliefs (just as any other believes) are real, not just metaphors, but their ontological status is different from objects like chairs or tables - they are more like centers of gravity (Tollefsen, 200, pp. 405-406). It seems to me though that there are some important distinctions between the intentionality of groups and the intentionality of individuals that should not be ignored; furthermore, I think that instrumentalist interpretations of the intentional strategy may be easier to understand for the readers that are less familiar with Dennett's work - and that is why I prefer the instrumentalist approach. But in the end, my main point, that is the claim that the intentional strategy can handle group believes better than Gilbert's joint commitment account, remains the same for both instrumentalist and intepretationist uses of the intentional strategy, and I will therefore leave it to the reader to decide between instrumentalism and interpretationism.

21 Gilbert (2002b, pp. 136-137). 
ems to me that there is a much simpler explanation. Roz feels offended simply because Mark lied to her. ${ }^{22}$ When Roz said "We believe that defensive war is justified", she did not utter a true sentence about an existing collective belief that Mark (unbeknownst to her) has violated (which is what is happening in Gilbert's analysis of the situation). Rather, she uttered a false sentence about her and Mark's mental states - and that sentence surely must have been false, because it was formed on the basis of a false premise (Mark's deceiving claim that he believes that defensive war is justified). This interpretation, it seems to me, provides satisfying enough answers without the need to postulate new entities like collective beliefs or joint commitments. A simple summative account is all we need here, and therefore, respecting the old and sacred rule of Occam's razor, it should be preferred.

Gilbert's other examples - the poetry club and the campus committee - will be more interesting. On the one hand, there might arise a situation in which the analysis would be similar to the case of Roz and Mark. For example, if a member of the poetry club, after the session described before, says something like: "Fine, we all believe that the poem is good", she is quite clearly claiming that every member of the club does believe so individually - and is wrong in saying that, again, because her claim is based on the lies of other members about their mental states. On the other hand, though, in different situations the ascriptions of mental states might be justified. If the students discussing the new café on campus say things like "Well, the new café will be built because the campus improvement committee wants one", it would be reasonable to interpret this claim as a case of assuming the intentional stance towards a group that these students cannot interpret otherwise. Notice I say that assuming the intentional stance is reasonable rather than that the sentence is true. Talking about the truth or falsity of sentences ge-

22 Or has changed his mind without letting her know. This will in most cases depend on the time that has passed between Mark's utterance that he believes that defensive war is justified and his denial of this claim. Had it happened within one day, Roz would surely feel that Mark has lied to her. But if a whole year has passed between the two conversations (with no relevant discussion on the topic in the meantime), Roz might just think that Mark has changed his mind. I suppose that her anger towards him would be much less intense in this case - exactly in accordance with the claim that the reason for her anger is Mark's lying, not violating some sort of binding commitment (which would be as relevant years after as it was the day it was formed). 
nerated via the intentional strategy can generally be quite tricky - not only in the case of groups, but even in cases the strategy was originally intended for (are the sentences "The chess program wants to take your queen" or "The cat thinks she owns the place" true or false?). This is not a problem of the intentional strategy though, it is a problem of any sentence in natural language that does not directly describe some state of affairs in the world. Think about sentences like "It's raining cats and dogs" or "Some unicorns have wings". Literally, these sentences are, of course, false, but if we understand what role they play in their specific language games, they can sometimes be considered true (in the first case if it is raining heavily when the sentence is uttered; in the second case if it is claimed in the context of some fantasy or mythical story in which there exists a creature that looks like a horse with a horn and wings). Similarly, the sentence "The campus improvement committee wants to build a new café" can be considered true in a discussion in which all the speakers understand that they are treating the committee as an intentional agent for the sake of simplicity or for a better understanding of its actions. But this context can be easily overthrown and the sentence made false if, for example, someone were to say: "They actually don't even want it, they are just afraid of the chancellor". By saying this, the intentional stance assumed in the discussion so far is replaced by a physical stance (which is, as we already saw, equivalent to what Gilbert calls a simple summative account and generally describes reality more precisely than the intentional or design stance). Thus, the sentence "The committee wanted a new café" (in this new interpretation meaning that every member of the committee wanted it) can no longer be considered true.

Last, let us take a look at the suggested counterexamples to treating collective beliefs as acceptances. These are all, quite obviously, cases of assuming an intentional stance towards specific social groups. The case of large-scale voting is indeed quite common in our everyday talk, but it is also the most problematic of these examples, since it can very often generate misleading or even false predictions and interpretations. We can again turn to the Brexit example: claiming (immediately after the Brexit referendum) that Britons wanted to leave the EU would probably 
be acceptable, but it surely would not be a very precise description of the political situation in the post-Brexit United Kingdom. The second example - the problem of governmental discussion about financing its military - presents a much better case of utilization of the intentional strategy. While in the case of large-scale voting it is usually not difficult to find the actual percentages of votes for all the different sides (and therefore the intentional strategy is not really necessary and a more precise description should be preferred), in the case of the governmental discussion we can imagine that not many people actually know how the conclusion was reached. These people are therefore not usually in the position to say that the final military budget was a compromise between two sides with extremely different opinions about the probability of an attack. Rather, somebody with no information about the discussion might just say "The government decided to invest more money in the military because it believed that the attack was quite probable" - thus providing a good enough explanation of the government's action without the need to know the mental states of the individual members of the government. The final example moves us from explanations to predictions. The criminals from this (highly hypothetical) situation do not know how the police typically handle such situations or how the chief of police will react to the information he got. And even if they did, it would still be quite complicated to guess and describe what is actually happening at the police station, what information and orders the chief gives to his subordinates, and how this will affect the beliefs of those individual subordinates. But this is not necessary. Assuming an intentional stance towards the police force and treating it as an agent who has a goal to fight crime and who just obtained information about a crime going on will give us a solid prediction of the future actions of this agent, which is all the criminals need (they would probably come to a similar conclusion if they assumed a design stance and treated the police force as a "machine" designed to react to criminal activity in a specific way - the fact that there may be grey areas between individual stances should not surprise us).

To briefly and clearly summarize the argument I have presented in this paper: in our everyday talk about collective mental states, we do not, 
as Margaret Gilbert claims, refer to some specific sort of collective agreements, which Gilbert calls joint commitments, nor do we mean by collective belief something different than belief as, for example, acceptance, as some critics of Gilbert have proposed. What we actually do when we talk about the mental states of groups is similar to what we do when we talk about the mental states of objects, animals or even humans we are using a strategy of interpreting, explaining and predicting the world around us based on our ability to understand intentions, desires, feelings and other mental states. This strategy, originally described by Daniel Dennett, is called the intentional strategy - and while it is not a perfect tool for describing or understanding the behaviour of groups, it is good enough in most everyday situations and, at the same time, is easy and intuitive enough for human beings to use effortlessly, which is why it is used so widely and why it presents such an interesting subject for philosophical study.

\section{References}

Dennett, D. C. (1971): "Intentional Systems." The Journal of Philosophy 68 (4): 87-106.

Dennett, D. C. (1981): “True Believers: The Intentional Strategy and Why It Works.” In Mind Design II: Philosophy, Psychology, and Artificial Intelligence, ed. J. Haugeland, The MIT Press, Cambridge, MA, London, 1997, pp. 57-80.

Gilbert, M. (1987): “Modelling Collective Belief.” Synthese 73 (1): 185204.

Gilbert, M. (2002a): “Acting Together.” In Joint Commitment: How We Make the Social World, M. Gilbert, Oxford University Press, Oxford, 2014, pp. 23-36.

Gilbert, M. (2002b): "Belief and Acceptance as Features of Groups.” In Joint Commitment: How We Make the Social World, M. Gilbert, Oxford University Press, Oxford, 2014, pp. 131-162.

Gilbert, M. (2002c): "Collective Guilt and Collective Guilt Feelings.” In Joint Commitment: How We Make the Social World, M. Gilbert, Oxford University Press, Oxford, 2014, pp. 229-256. 
Gilbert, M. (2004): “Collective Epistemology.” In Joint Commitment: How We Make the Social World, M. Gilbert, Oxford University Press, Oxford, 2014, pp. 163-180.

Gilbert, M. (2014): Joint Commitment: How We Make the Social World. Oxford University Press, Oxford.

Hakli, R. (2007): "On the Possibility of Group Knowledge without Belief.” Social Epistemology 21 (3): 249-266.

Mathiesen, K. (2006): "The Epistemic Features of Group Belief." Episteme 2 (3): 161-175.

Rowlands, M. (2012): Can Animals be Moral? Oxford University Press, New York.

Schmitt, F. (2014): “Group Belief and Acceptance.” In From Individual to Collective Intentionality: New Essays, eds. S. R. Chant, F. Hindriks \& G. Preyer, Oxford University Press, New York, 2014, pp. 61-96.

Sheehy, P. (2006): The Reality of Social Groups. Ashgate, Aldershot. Tollefsen, D. P. (2002): “Organizations as True Believers.” Journal of Social Philosophy 33 (3): 395-410.

Tollefsen, D. P. (2015): Groups as Agents. Polity Press, Cambridge, UK, Malden, MA.

Tuomela, R. (2000): "Belief versus acceptance.” Philosophical Explorations 3 (2): 122-137.

\begin{abstract}
Abstrakt
Kolektivní přesvědčení a intencionální strategie

Co přesně máme na mysli, když říkáme, že je nějaká skupina o něčem přesvědčená? Myslíme tím pouze to, že jsou o dané věci přesvědčení všichni členové této skupiny, nebo tím snad přiznáváme existenci nějakého kolektivního agenta? Podle Margaret Gilbertové výroky o mentálních stavech skupin popisují specifický typ dohody, kterou nazývá společný závazek (joint commitment) - jinak řečeno, jsme-li o něčem přesvědčeni společně, znamená to, že jsme společně s ostatními zavázáni $\mathrm{k}$ tomuto přesvědčení. Ve svém článku nejprve podrobněji představím přístup Gilbertové, nicméně následně poukáži na některé s ním spojené problémy, které povedou k jeho odmítnutí. Následně nastíním nejčastějšś řešení uvedených problémů, které spočívá $\mathrm{v}$ nahrazení kolektivního přesvědčení přitakáním (acceptance). Budu ovšem argumentovat, že ani toto řešení není uspokojivé. Ǩe-
\end{abstract}


šení, které posléze navrhnu, je založené na tzv. intencionální strategii Daniela Dennetta, což je metoda interpretace a predikce chování věcí kolem nás tím způsobem, že tyto věci chápeme jako racionální agenty s odpovídajícími záměry. Pokusím se ukázat, že veškeré problematické případy kolektivního přesvědčení jsou řešitelné aplikováním intencionální strategie na dotčené skupiny.

Klíčová slova: Daniel Dennett, intencionální strategie, kolektivní přesvědčení, Margaret Gilbertová, společný závazek

Kocourek, D. (2019): „Collective Belief and the Intentional Strategy.“ Filosofie dnes 11 (2): 57-75. Dostupné z www.filosofiednes.ff.uhk.cz 